\title{
MULTIPLE 3D APPROACHES FOR THE ARCHITECTURAL STUDY OF THE MEDIEVAL ABBEY OF CORMERY IN THE LOIRE VALLEY
}

\author{
T. Pouyet ${ }^{\mathrm{a}}$ \\ a UMR 7324 CITERES - Laboratoire Archéologie et Territoires, University François-Rabelais de \\ Tours, Tours, France, \\ thomas.pouyet@univ-tours.fr
}

Commission II

KEY WORDS: Archaeology, Architecture, Church, Drawing, Drone, Laser Scanning, Photogrammetry.

\begin{abstract}
:
This paper will focus on the technical approaches used for a $\mathrm{PhD}$ thesis regarding architecture and spatial organization of benedict abbeys in Touraine in the Middle Ages, in particular the abbey of Cormery in the heart of the Loire Valley.

Monastic space is approached in a diachronic way, from the early Middle Ages to the modern times using multi-sources data: architectural study, written sources, ancient maps, various iconographic documents... Many scales are used in the analysis, from the establishment of the abbeys in a territory to the scale of a building like the tower-entrance of the church of Cormery. These methodological axes have been developed in the research unit CITERES for many years and the 3D technology is now used to go further along in that field.

The recording in $3 \mathrm{D}$ of the buildings of the abbey of Cormery allows us to work at the scale of the monastery and to produce useful data such as sections or orthoimages of the ground and the walls faces which are afterwards drawn and analysed. The study of these documents, crossed with the other historical sources, allowed us to emphasize the presence of walls older than what we thought and to discover construction elements that had not been recognized earlier and which enhance the debate about the construction date St Paul tower and associated the monastic church.
\end{abstract}

\section{INTRODUCTION}

The abbey of Cormery, located 20 kilometres south-east of the city of Tours, was founded in 791 by Ithier, abbot of St Martin and Charlemagne's grand chancellor.

This small cella was at the beginning under the direction of St Martin of Tours and became a monasterium a few years later. Cormery chooses to follow the Benedictine rule during the Carolingian monastic reform. Monks from Benoit d'Aniane's monasteries reformed with the Benedictine rule came to the abbey to teach this way of living.

According to the cartulary, the abbey was rebuilt several times between the $8^{\text {th }}$ and the $10^{\text {th }}$ centuries. A new church was dedicated in 1054 and some architectural parts of this period are still standing nowadays.

Many buildings of the abbey were built during the medieval period like the cellar in the $12^{\text {th }}$ century or the stately refectory in the $13^{\text {th }}$. At the end of the $15^{\text {th }}$ century, an important defensive building phase was undertaken with the construction of walls surrounding the monastery. During the $17^{\text {th }}$ century, Cormery joined St Maur Congregation which was attempting to re-establish the Benedictine spiritual life and undertook in this purpose the reorganization of the monastic space.

The oldest maps and engravings of Cormery were produced at this period, like the plan of 1674 (Figure 4). The St Maur monks also collected and copied the medieval charters. This collection of documents was published in the $19^{\text {th }}$ century as the cartulary of Cormery, which constitute the main archive source for the history of Cormery (Bourasse, 1861).
This cartulary has been exploited by historians since the $19^{\text {th }}$ century and the construction dates of the buildings were interpreted with this point of view.

The abbey of Cormery was abandoned by the monks at the end of the $18^{\text {th }}$ century after the French Revolution (Bourasse, 1861, Chupin, 1995). Some buildings were occupied and modified by the inhabitants of the village like the refectory or the Chapter house. Others buildings like the abbey church were almost completely destroyed, with a road going through the nave and houses built in the aisles (Figure 2). The exhaustive study of the site is consequently quite complex because the different parts of the abbey are owned by a large number of people.

In the 1960s, the art historian Charles Lelong (Lelong, 1966) published an article about St Paul tower, placing the construction date of the building at the end of the $11^{\text {th }}$ century, according to his work about Roman architecture in Val de Loire (Lelong, 1977). This dating was reassessed by the art historian Eliane Vergnolle who proposed a different construction chronology between the tower and the church (Vergnolle, 1985).

During the 1990s, the Inventaire Général du Patrimoine Culturel (Mauret-Cribellier, 1994) carried out an important project at Cormery, collecting pictures of the architectural remains and surveying parts of the cloister and St Paul tower (Figure 1). 


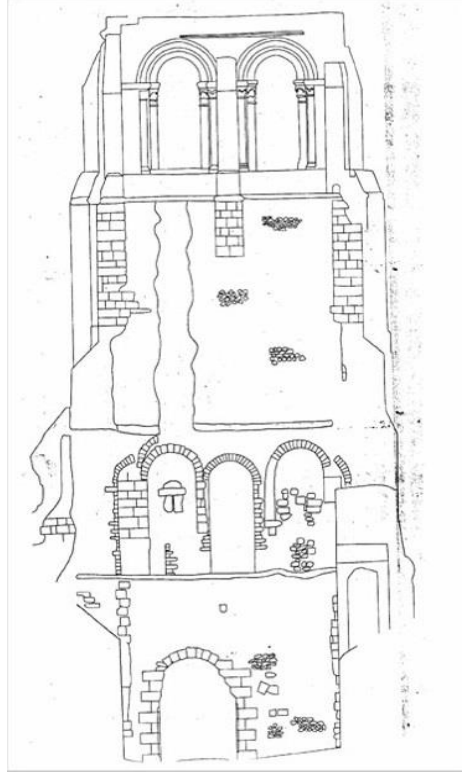

Figure 1. St Paul Tower at Cormery. Photogrammetric recording of the east facade by the Inventaire Général du Patrimoine Culturel in 1994

Within the PhD framework, the production of new surveys was necessary to work on the whole monastery, from the scale of the building to the scale of the stones. A special attention was given to St Paul tower which needed several kinds of survey to get a satisfactory result.

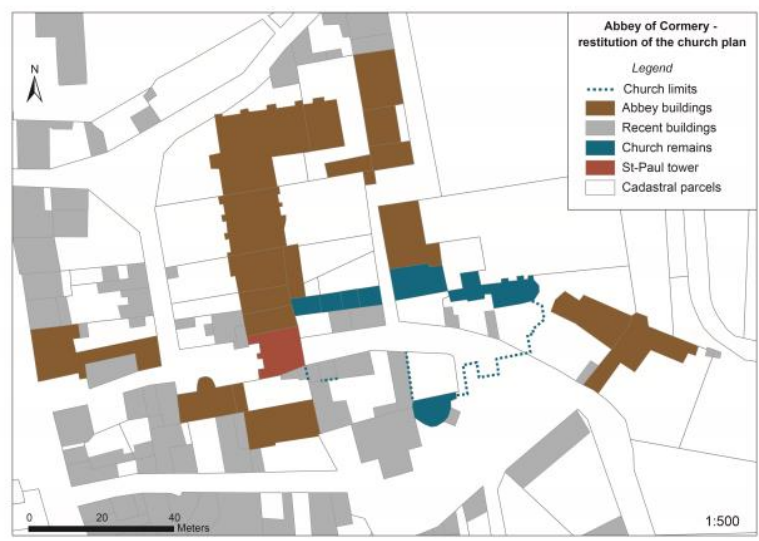

Figure 2. Map of the abbey of Cormery with the church limits

\section{RELATED WORKS}

The use of 3D approaches (laser scanning and photogrammetry) has already be experimented for wide and complex archaeological sites such as castles (D'Agostino et al., 2013, Barreau et al., 2014) providing data which would have been difficult and time-consuming to produce by hand drawing.

The reading of several case studies (De Luca, 2011, Guidi, 2014, Macher et al., 2015) allowed us to plan a specific solo approach without the need of a survey team on the field.

\section{METHOD OF APPROACH WITH LASER}

\subsection{Main laser scanning campaign in 2015}

3D technology was very useful to survey the site, divided into several owners. In 2015 a laser scanning campaign was carried out on parts easily accessible which belong to the municipality of Cormery. Ten days were needed to record 250 scans and one month of post-processing to generate the final points cloud.

The outside parts were recorded with a high resolution and precision in order to get all the details of the stones on the wall faces: resolution of $1 / 4$ (density of one point every $6 \mathrm{~mm}$ at 10 meters) and a quality of 4 (laser rotation speed). Some interior parts were recorded with less precision: resolution of $1 / 5$ (density of one point every $7.6 \mathrm{~mm}$ at 10 meters) and a quality of 3 .

The scanning was performed with a Faro Scanner and the postprocessing made with the software FaroScene. At the end all the scans were gathered in a single points cloud, using the spheres placed during the progression of the laser recording and adding marks and common references to the scans to get a more precise registration.

At this point, it was already possible to analyse the architecture of the main buildings of the abbey, even without a complete survey of the site.

\subsection{Gradual addition of data in the final point cloud}

Other small laser scanning surveys were carried out later in 2016 to record the remains located in private houses, basements or garages. The new data were added and registered into the final laser scanning project.

Afterwards we exported some defined parts of the points cloud to be able to work on a specific area or building like the ancient church. Even with a supercomputer, it was indeed difficult to manipulate and exploit the whole points cloud of the abbey.

Each point cloud selection was afterwards exploited in the proprietary software PointCab to produce the data needed for the analysis of the architecture and the understanding of the monastic space.

\subsection{Feedback about this laser scanning survey}

The purpose of this article is not to prove the advantages of the laser scanning for standing building studies which are used to survey architecture for many years (Fuchs, 2004).

In this case it was particularly fast and useful to cover the whole surface of the abbey (two weeks) even if it was then timeconsuming and difficult to register the scans together, due to the steps made during the laser recording. The three-dimensional acquisition can be exploited on a supercomputer without time limit and allow much experimentation for the analysis of the architecture.

\section{EXPLOITATION OF THE POINT CLOUD}

Three kinds of documents are generated manually for this purpose: orthoimages of the ground, sections and orthoimages of the walls faces.

\subsection{Ortho-plans}

Orthoimages of the ground are extracted and afterwards digitized to draw precise plans of the monastic buildings (Figure 3). These plans are then integrated in GIS software and 
georeferenced with GPS data (centimetric precision) taken on the site, allowing us to represent in 2D the chronology and the functions of each part of the abbey after data-crossing.

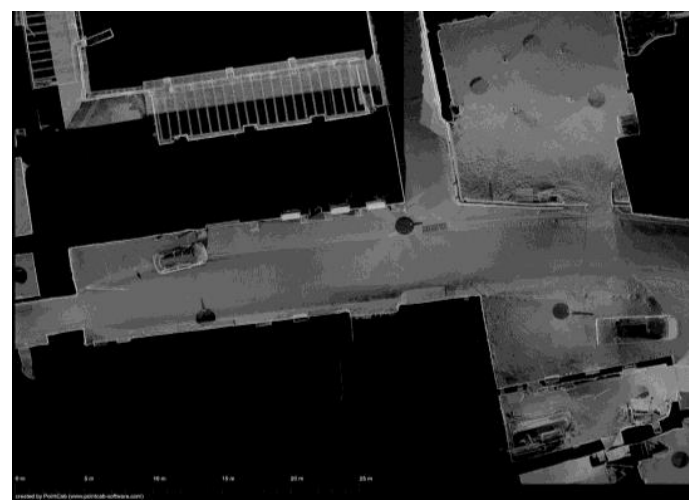

Figure 3. Orthoimage of the location of the nave

Using GIS gives us the possibility to compare the existing remains with the location of buildings in the plans and maps created between the $17^{\text {th }}$ and the $19^{\text {th }}$ century. For example, the georeferenced map of the figure 4 dates back to 1674 (Paris, Archives nationales, CPNIII_Indre-et-Loire), when St Maur Congregation tried to renovate monastic life by modifying the spatial organization of the monastery.

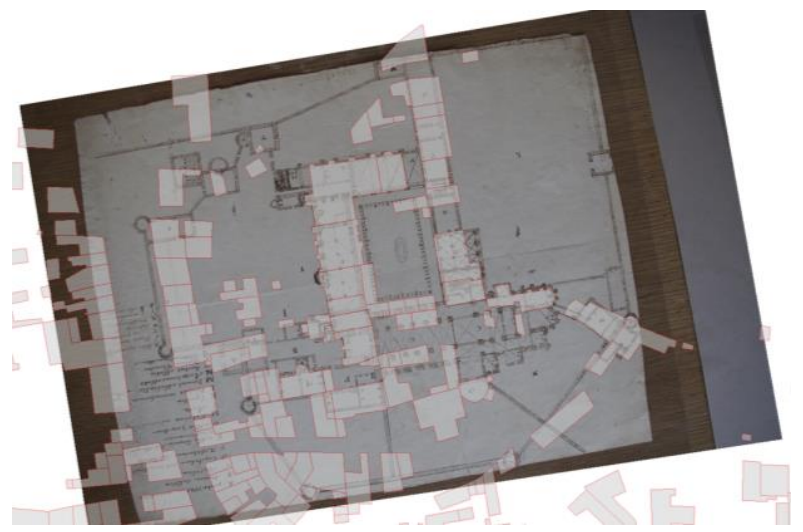

Figure 4. Map of the abbey of Cormery produced in 1674

\subsection{Sections}

There are used at the scale of the abbey to understand the difference of levels between the buildings of the monastery, especially for understanding of the gap between the ground level of the refectory, the cloister and the church.

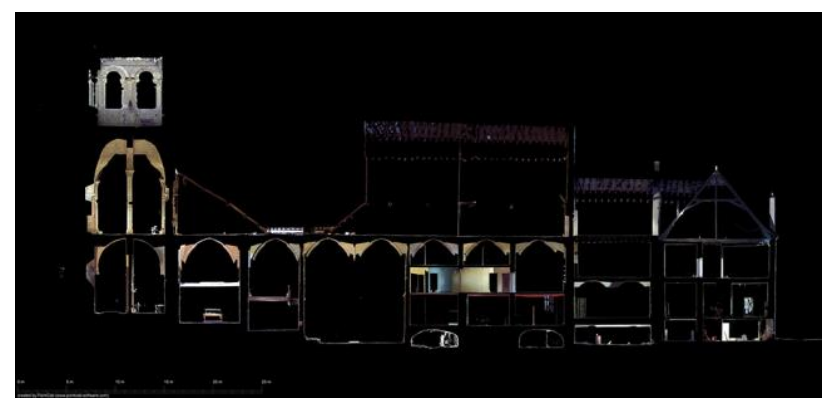

Figure 5. Section north-south with tower, refectory and kitchen
At the building scale, it's for example helpful to analyse the layout of the buttresses in the gallery of the cloister or on the refectory. The gutter walls of this last building were modified with different kinds of windows between east and west. With the same idea, sections on framework can help to understand the modification of the space, especially in the old kitchen at Cormery where the connections between the buildings of the cloister changed several times during the medieval period (Figure 6).

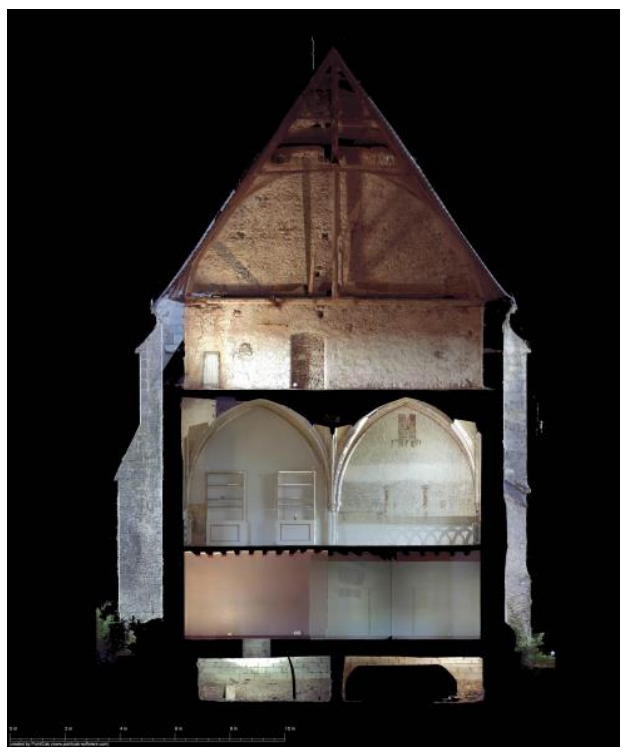

Figure 6. Section south of the kitchen

At the structural scale, like the pillars of the refectory which base section allows to suggest a morphological dating: the $13^{\text {th }}$ century in this case. This interpretation matches with the clues about the construction date mentioned in the written sources between 1231 and 1241, under the direction of the abbot Jean III.

\subsection{Photomosaic}

The last kinds of document used are the photomosaic of the walls faces which are drawn afterwards with CAD (Computer Assisted Design) software. Orthophotos of the walls located outside provided better results than inside, like for example the still-existing apse chapel of the church (Figure 7). Laser scanning is particularly well adapted to this kind of wall in ashlar, more than for small-stone apparatus which were also used at Cormery (Figure 8).

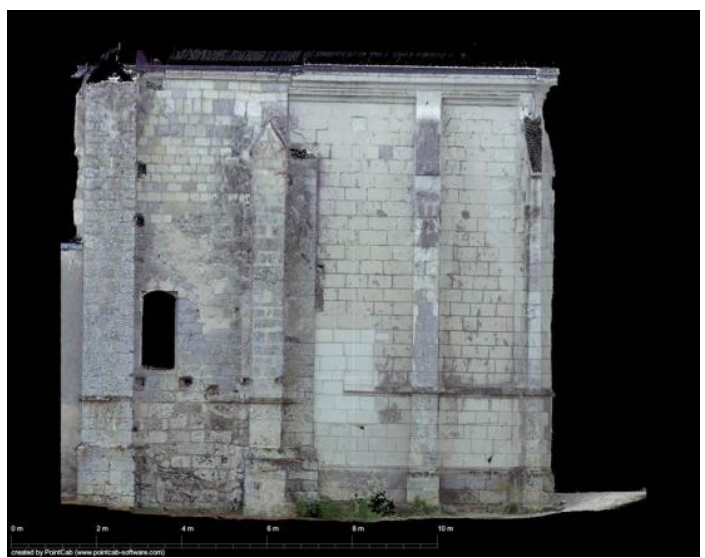


Figure 7. Orthoimage of the north wall of the Du Puy chapel

\subsection{Feedback about the 3D exploitation}

Laser scanning was however not really efficient in some particular cases like the tower-entrance of the church $\mathrm{r}$. The laser scanning record with a high resolution provided a very good precision for the lower part of the tower. However, it gave us a far less satisfactory precision for the upper part, because of the distance between the laser sensor and the top of the tower and some difficulties to assemble the tower scans together. It wasn't indeed possible to make a continuous progression with laser between the three floors of the building.

\section{PHOTOGRAMMETRY}

\subsection{Ground photogrammetry}

To survey correctly the walls faces, we tried to use the photogrammetric method from the bottom of the tower with a camera Pentax $\mathrm{Kr}(23.6$ x $15.8 \mathrm{~mm}$ CMOS sensor, 12 million pixels) and a $18-55 \mathrm{~mm}$ lens. The orthoimage have then been produced with the SFM software Mic-Mac providing better results for the upper part of the tower but still not satisfying enough for stone by stone survey.

Beside the tower's case, some other parts located inside required the use of photogrammetry to survey in a very short time, like the north part of the transept which was transformed into storage place and was accessible for only one hour.

Photogrammetry was also used to work on the wall built with small stones apparatus which needs a very good precision for stone by stone drawing. These kinds of walls are usually attributed to the $11^{\text {th }}$ century, but they could also have been constructed during the $10^{\text {th }}$ century because this building method was used all along the early Middle Ages (Prigent, 2012).

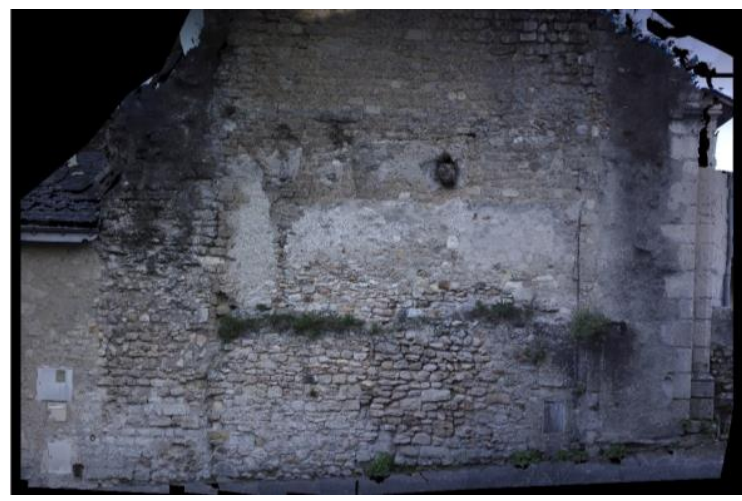

Figure 8. Orthoimage of the west wall of the north transept church

\subsection{UAV using}

The recent purchase of a small UAV by the laboratory allowed us to try the first flight on St Paul tower and to photograph each wall in a very close range with a low resolution GoPro sensor (72 dpi, 2624 x 1968 pixels). Pictures were post-processed with Agisoft PhotoScan to finally produce the best orthoimage of the three tested methods. Despite the use of a very small captor (GoPro HERO3+ Silver Edition), the very-close range enabled us to produce the best digital image (Figure 9).

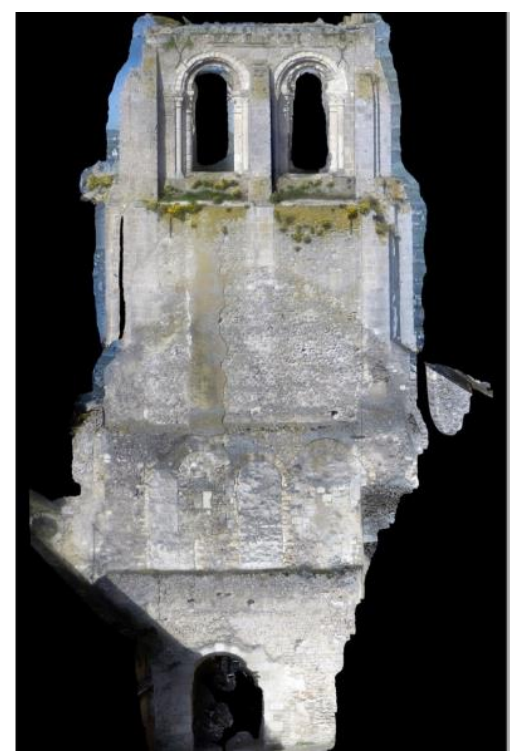

Figure 9. Orthoimage of the east face of St Paul tower

\section{EXPLOITATION OF THE RESULTS}

\subsection{The case of St Paul tower}

The study of sections and orthoimages produced with 3D technology allowed us to emphasize some important elements. Firstly, the existence of projections on the remaining face of the church wall which is stuck on the tower. The upper projection could be the trace of a floor. The lowest projection indicates a distinction between two walls faces and the three potential Carolingian plugged windows placed above it (in green on Figure 10).

This facade was already hard to understand with two architectural phases modified between the $10^{\text {th }}$ and the $11^{\text {th }}$ century, which are probably the witnesses of a change in the liturgy adopted by the Benedictine monks. Keeping only two windows (in brown on Figure 10) between the church and the tower, showed the will to respect a more intimate liturgy.

Studying the orthophoto, we highlight a third architectural phase (in red on Figure 10), pictured by some arched stones at the left side of the wall.

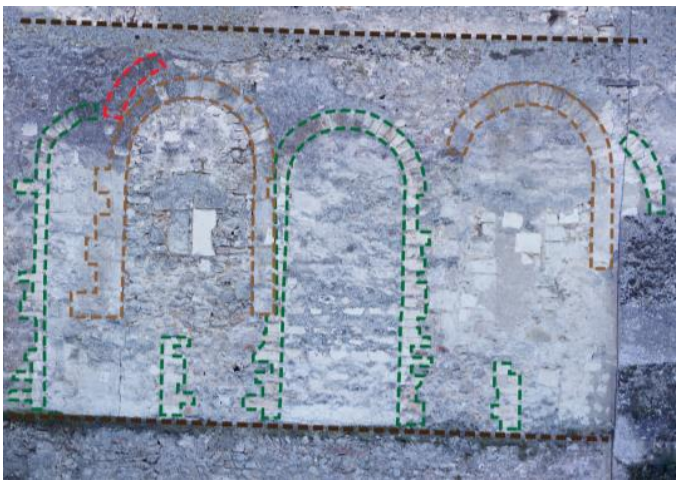

Figure 10 - Projections and plugged windows on the east face of St Paul tower. 


\subsection{Occupation levels}

The monastery was built in a hillside with the cloister on the north of the church, towards the river which forms a naturel barrier on the north. With this kind of sections (Figure 5), we enlightened the fact that the church, the heart of the monastery, was constructed at the highest level of the area, dominating the other buildings of the abbey.

Some level differences are still difficult to explain, like the gap between the floor level of the refectory and the cloister. This area was probably modified during the $14^{\text {th }}$ or the $15^{\text {th }}$ century and the cloister floor enhanced. Some excavations will be carried out in the summer 2017 to check these facts.

\section{CONCLUSION}

The goal of this 3D use lies in the analysis of architectural features without producing a perfect $3 \mathrm{D}$ model. This is not about filling gap in the 3D model or restoring the missing parts of the buildings. The data are finally produced in 2D and exploited afterwards by drawing and recording the stones and others architectural elements without any kind of automatic extraction (which is now possible: Landes, 2014).

The main point is clearly to generate $3 \mathrm{D}$ clouds which can be manipulated and exploited in many ways, always for the purpose of enhancing the comprehension of the architecture of the monastery.

The only possibility of modelling envisaged will be the production of a wire frame model to test hypotheses of architectural restitution without mesh and texture.

In the future, in the process of preservation and enhancement of this cultural heritage, the 3D data gathered for the architectural study could be used to create a 3D model of the abbey of Cormery in the medieval times, when the analysis will be completed.

\section{REFERENCES}

Bourassé, J.-J., 1861. Cartulaire de Cormery, Mémoires de la société archéologique de Touraine, Tome XII.

Barreau, J-B., Bernard, Y., Petit, Q., Beuchet, L., Petit, E., et al., 2014. Combination of 3D scanning, Modeling and Analyzing Methods around the Castle of Coatfrec Reconstitution. International Conference on Culturage Heritage, EuroMed, 2014, Nov 2014, Lemessos, Cyprus. pp.418 - 426, 2014

Chupin, A., 1995. Cormery 1791-1820, le dépeçage d'une abbaye millénaire. Bulletin de la Société Archéologique de Touraine, tome XLIV.

D’Agostino, L., Guffond, C., Sartorio, G., Veissiere, O., Bryer, A., 2013. Lasergrammétrie et photogrammétrie appliquées à l'étude archéologique des châteaux médiévaux : le programme franco-italien AVER - Des montagnes de châteaux, Revue française de photogrammétrie et de télédétection, 201, pp. 1326.
De Luca, L., 2011. Methods, formalisms and tools for the semantic-based surveying and representation of architectural heritage. Applied Geomatics, pp. 1-25.

Fuchs, A., Alby , E., Begriche, R., Grussenmeyer, P., Perrin, JP., 2004. Confrontation du relevé laser 3D aux techniques de relevé conventionnelles et de développement d'outils numériques pour la restitution architecturale. Revue de la Société Française de Photogrammétrie et de Télédétection $\mathrm{n}^{\circ}$ 173/174 (2004-1/2), 2004. pp. 36-47.

Guidi, G., 2014. Terrestrial optical active sensors - Theory and applications. In: 3D Recording and Modelling in Archeology and Cultural Heritage - Theory and Best Practices, F. Remondino and S. Campana (Eds), Archaeopress BAR Publication Series 2598, pp. 37-59.

Landes, T., Bidino, S., Guild, R., 2014. Semi-automatic extraction of sectional view from point clouds. The case of Ottmarsheim's abbey church. In: The International Archives of the Photogrammetry, Remote Sensing and Spatial Information Sciences, ISPRS Technical Commission V Symposium, 23 - 25 June 2014, Riva del Garda, Italy, Vol. XL-5, pp. 343-348.

Lelong, C., 1966. Vestiges romans de l'église abbatiale de Cormery. In Bulletin Monumental, Vol. 124, n 4, pp. 381-387.

Lelong, C., 1977. Touraine romane, $3^{\mathrm{e}}$ édition, Coll. La Nuit des temps, Zodiaque, Saint-Léger-Vauban.

Macher, H., Grussenmeyer, P., Kraemer, C., Guillemin, S., 2015. Overview of 3D documentation data and tools available for archaeological researches: case study of the romanesque church of Dugny-sur-Meuse (France). In: The International Archives of the Photogrammetry, Remote Sensing and Spatial Information Sciences, $201525^{\text {th }}$ International CIPA Symposium 2015, 31 August - 04 September 2015, Taipei, Taiwan, Vol XL-5/W7, pp. 323-330.

Mauret-Cribellier, V., 1994. L'abbaye bénédictine Saint-Paul de Cormery (Indre-et-Loire), In Bulletin de la Société Archéologique de Touraine, tome XLIV, pp. 119-143.

Prigent, D., 2012. Le petit appareil : méthodes d'analyse et premiers résultats, l'exemple du Val de Loire, In Le "premier art roman" cent ans après : la construction entre Saône et Pô autour de l'an mil : études comparatives, actes du colloque international de Baume-les-Messieurs et Saint-Claude 17-21 juin 2009, Presses universitaires de Franche-Comté, pp.189204.

Vergnolle, E., 1985. Saint-Benoît-sur-Loire et la sculpture du $\mathrm{XI}^{\mathrm{e}}$ siècle, Picard, Paris. 